\title{
PCR Primers for Detection of Pantoea ananatis, Burkholderia spp., and Enterobacter sp. from Onion
}

Jo Ann E. Asselin, Jean M. Bonasera, and Steven V. Beer, Section of Plant Pathology and Plant-Microbe Biology, School of Integrative Plant Science, Cornell University, Ithaca NY 14853

\begin{abstract}
Asselin, J. E., Bonasera, J. M., and Beer, S. V. 2016. PCR primers for detection of Pantoea ananatis, Burkholderia spp., and Enterobacter sp. from onion. Plant Dis. 100:836-846.

Bacterial decays of onion bulbs cause sporadic and sometimes serious losses to onion (Allium cepa). In New York, three groups of bacteria were identified as problematic: Burkholderia spp., Pantoea ananatis, and Enterobacter spp. To aid in efficient detection and diagnosis of these pathogens, pairs of specific polymerase chain reaction primers were designed and validated, based on a strategy that utilized various genome

sequences now available in public databases. Primer pairs were tested against numerous strains of target bacteria, closely related bacteria, and other onion-pathogenic bacteria. Each primer pair yielded a single, apparently highly specific amplicon from aqueous suspensions of the target bacteria. Minimum sensitivities were approximately $10^{3} \mathrm{CFU}$ per $25-\mu \mathrm{l}$ reaction mixture for all three primer pairs.
\end{abstract}

Onion (Allium cepa) bulbs are susceptible to a number of diseases caused by bacteria. Symptoms can range from slight discoloration of one or a few internal scales to severe maceration of almost the entire bulb (Schwartz and Mohan 2008). Losses are a continuing and sometimes severe problem for onion growers. Symptom development can occur during the growing season or during harvest, curing, and cold storage of bulbs prior to marketing. Different bacterial pathogens cause different symptoms in onion bulbs. However, symptoms are not sufficiently distinct to serve as identifiers of a causal organism, especially for bulbs with advanced disease. Mixed infections and the presence of secondary invaders are common and can create confounding combinations of symptoms. In New York State, several bacterial pathogens of onion have been identified, including Pantoea ananatis (Carr et al. 2010) and species of Burkholderia (Burkholder 1950) and Enterobacter (Zaid et al. 2011) (hereinafter target bacteria).

Several species of Burkholderia (Burkholderia gladioli, B. cepacia, and $B$. cenocepacia) have been described previously as onion pathogens (Burkholder 1942, 1950; Sotokawa and Takikawa 2004). Onion diseases caused by Burkholderia spp. are characterized by water soaking and maceration of infected bulb scales. B. cepacia and B. cenocepacia belong to the Burkholderia cepacia complex (BCC), a group of at least 20 closely related species within the genus Burkholderia (De Smet et al. 2015; Peeters et al. 2013; Vandamme and Peeters 2014). BCC bacteria and B. gladioli are also opportunistic human pathogens, causing serious infections in individuals with cystic fibrosis or chronic granulomatous disease. As such, polymerase chain reaction (PCR)based tools to identify these strains were developed previously to aid in diagnosis of clinical infections. These tools include primers that produce amplicons from strains of the BCC or broadly from the genus Burkholderia (Mahenthiralingam et al. 2000; Payne et al. 2005). Primers have also been reported for detecting particular species of the BCC or B. gladioli (Mahenthiralingam et al. 2000; Whitby et al. 2000). However, the continued delineation of species within

Corresponding author: S. V. Beer, E-mail address: svb1@ cornell.edu

*The $\boldsymbol{e}$-Xtra logo stands for "electronic extra" and indicates that two supplementary figures are published online.

Accepted for publication 21 October 2015.

http://dx.doi.org/10.1094/PDIS-08-15-0941-RE

(C) 2016 The American Phytopathological Society the BCC means that PCR and other protocols identifying strains to the species level must be revalidated as changes in taxonomy are made.

$P$. ananatis is a pathogen of several food crops and causes center rot of onion. Symptoms of $P$. ananatis infection in onion plants include lesions on the leaves and a yellow-brown discoloration of bulb scales in infected bulbs. Similar symptoms can be caused by pathogenic strains of the related species $P$. agglomerans (Hattingh and Walters 1981) and P. allii (Brady et al. 2011). Several primer sets have been published previously (Carr et al. 2010; Figueiredo and Paccola-Meirelles 2012; Gitaitis et al. 2002). All are based on detection of the multiple copy $16 \mathrm{~S} / 23 \mathrm{~S}$ ribosomal internal transcribed spacer (ITS) regions. In addition to $P$. ananatis, these primers also reportedly amplify DNA of at least one strain of $P$. stewartii (Gitaitis et al. 2002) or strains of $P$. allii (Figueiredo and Paccola-Meirelles 2012).

The symptoms of Enterobacter bulb decay of onion are usually mild, with discolored internal scales and no maceration. The disease is usually noted as a problem in cold storage (Schwartz and Otto 2000; Zaid et al. 2011) but it has been described as a late-season disease in the field following periods of excessive heat (Bishop and Davis 1990; Schroeder and du Toit 2009). Recent work suggested that the species of Enterobacter most commonly isolated from onion in Washington may not be Enterobacter cloacae but, perhaps, another species of Enterobacter (B. Schroeder, personal communication). These strains appear to be pathogenic to onion in inoculation assays (B. Schroeder, personal communication). We are not aware of any diagnostic PCR primer pairs that amplify DNA from Enterobacter spp. generally, or the group of strains most commonly isolated from onion specifically.

In order to study the prevalence, timing, and sources of inoculum of bacterial pathogens of onion bulbs, accurate techniques for detecting decay pathogens are crucial. Pathogen-specific PCR primers producing single amplicons with genomic DNA from target bacteria are valuable for quickly and inexpensively detecting bacteria from a mixture or a pure culture. Here, we report the design and validation of three specific primer pairs for detection of the three important groups of bacteria that infect onion in New York. Each primer set is specific to a particular subset of bacteria: $P$. ananatis, BCC and $B$. gladioli, and the group of Enterobacter strains most commonly isolated from onion.

Our primer design strategy used genomic data in GenBank and other public databases to identify DNA sequences common to multiple strains of the bacteria of interest but absent from other genome sequences of bacteria. PCR primer pairs based on those sequences 
were designed and tested empirically using numerous target and nontarget bacterial strains.

\section{Materials and Methods}

Bacterial strains used in this study. Bacterial strains were routinely cultured on Luria-Bertani (LB) agar plates and incubated at
28 or $37^{\circ} \mathrm{C}$ for 1 to 2 days. For long-term storage, freshly grown bacterial strains were lifted from LB agar plates using sterile cottontipped applicators, suspended in $15 \%$ aqueous glycerol, and stored at $-80^{\circ} \mathrm{C}$. Separate sets of strains were used for assessing the specificity of primers designed to detect Burkholderia spp. (Table 1), $P$. ananatis (Table 2), and Enterobacter spp. (Table 3) toward target

Table 1. Strains used to test Burkholderia-specific primers

\begin{tabular}{|c|c|c|c|c|}
\hline Strain & Isolated from & Other number & Received from or reference & $\mathbf{A m p}^{\mathrm{a}}$ \\
\hline \multicolumn{5}{|l|}{$\overline{\mathrm{BCC}^{\mathrm{b}}}$} \\
\hline CU0318 & Onion & $64-22 \mathrm{NS}$ & Zaid et al. (2012) & + \\
\hline CU3094 & Soil, New Jersey & & & + \\
\hline CU3368 & Onion, 1948 & ATCC 25416 & Type strain of Burkholderia cepacia & + \\
\hline CU3370 & Soil, New Jersey & ATCC 39356 & & + \\
\hline CU6878 & Onion field soil, New York & Christy IV & Zaid et al. (2012) & + \\
\hline CU3372 & Forest soil, Trinidad & ATCC 17759 & & + \\
\hline CU3371 & Corn field soil, New Jersey & ATCC 39277 & & + \\
\hline D21 & Onion, New York & & S. V. Beer & + \\
\hline $\mathrm{E} 40 \mathrm{~b}$ & Onion, New York & & S. V. Beer & + \\
\hline $\mathrm{F} 37 \mathrm{~b}$ & Onion, New York & & S. V. Beer & + \\
\hline F40a & Onion, New York & & S. V. Beer & + \\
\hline $\mathrm{I} 49 \mathrm{a}$ & Onion, New York & & S. V. Beer & + \\
\hline I55b & Onion, New York & & S. V. Beer & + \\
\hline $\mathrm{J} 20 \mathrm{a}$ & Onion, New York & & S. V. Beer & + \\
\hline $\mathrm{J} 31$ & Onion, New York & & S. V. Beer & + \\
\hline J32a & Onion, New York & & S. V. Beer & + \\
\hline $\mathrm{J} 74 \mathrm{a}$ & Onion, New York & & S. V. Beer & + \\
\hline $\mathrm{J} 81 \mathrm{~b}$ & Onion, New York & & S. V. Beer & + \\
\hline J83a & Onion, New York & & S. V. Beer & + \\
\hline J96c & Onion, New York & & S. V. Beer & + \\
\hline $\mathrm{K} 21 \mathrm{~b}$ & Onion, New York & & S. V. Beer & + \\
\hline $\mathrm{K} 37 \mathrm{C}$ & Onion, New York & & S. V. Beer & + \\
\hline $\mathrm{K} 4 \mathrm{~b}$ & Onion, New York & & S. V. Beer & + \\
\hline L15a & Onion, New York & & S. V. Beer & + \\
\hline L24b & Onion, New York & & S. V. Beer & + \\
\hline L88a & Onion, New York & & S. V. Beer & + \\
\hline M17b & Onion, New York & & S. V. Beer & + \\
\hline M18a & Onion, New York & & S. V. Beer & + \\
\hline $\mathrm{M} 2$ & Onion, New York & & S. V. Beer & + \\
\hline \multicolumn{5}{|l|}{ B. gladioli } \\
\hline CU3082 & Onion, New York & & W. H. Burkholder & + \\
\hline CU3083 & Onion, New York & PA-23 & Yohalem and Lorbeer (1994) & + \\
\hline CU3890 & & ATCC 10248 & & + \\
\hline CU3891 & Onion bulb rot & ATCC 19302 & & + \\
\hline \multicolumn{5}{|c|}{ Similar to B. phymatum } \\
\hline $\mathrm{H} 49 \mathrm{a}$ & Onion, New York & & S. V. Beer & - \\
\hline $\mathrm{I} 44 \mathrm{a}$ & Onion, New York & & S. V. Beer & - \\
\hline $\mathrm{I} 49 \mathrm{~b}$ & Onion, New York & & S. V. Beer & - \\
\hline $\mathrm{I} 54 \mathrm{~b}$ & Onion, New York & & S. V. Beer & - \\
\hline $\mathrm{K} 37 \mathrm{~B}$ & Onion, New York & & S. V. Beer & - \\
\hline $\mathrm{K} 5 \mathrm{~b}$ & Onion, New York & & S. V. Beer & - \\
\hline L52a & Onion, New York & & S. V. Beer & - \\
\hline P19a & Onion, New York & & S. V. Beer & - \\
\hline $\mathrm{K} 3 \mathrm{~b}$ & Onion, New York & & S. V. Beer & - \\
\hline \multicolumn{5}{|c|}{ Burkholderia spp. } \\
\hline O64a & Onion, New York & & S. V. Beer & - \\
\hline \multicolumn{5}{|l|}{ Other genera } \\
\hline \multicolumn{5}{|c|}{ Pseudomonas protegens } \\
\hline $\mathrm{A} 60$ & Onion, New York & & S. V. Beer & - \\
\hline $\mathrm{H} 10 \mathrm{a}$ & Onion, New York & & S. V. Beer & - \\
\hline \multicolumn{5}{|c|}{ Pseudomonas putida } \\
\hline E65 & Onion, New York & & S. V. Beer & - \\
\hline \multicolumn{5}{|c|}{ Pseudomonas spp. } \\
\hline A1 & Onion, New York & & S. V. Beer & - \\
\hline $\mathrm{H} 40 \mathrm{c}$ & Onion, New York & & S. V. Beer & - \\
\hline \multicolumn{5}{|c|}{ Xanthomonas axonopodis pv. allii } \\
\hline CU6923 & Onion, $\mathrm{CO}$ & $\mathrm{O} 274$ & H. Schwartz, CSU ${ }^{c}$ & - \\
\hline
\end{tabular}

a Amplification with BAMB_5978 40F/350R

b Burkholderia cepacia complex.

${ }^{\mathrm{c}} \mathrm{CSU}=$ Colorado State University. 
Table 2. Strains used to test Pantoea ananatis-specific primers

\begin{tabular}{|c|c|c|c|c|}
\hline Strain & Isolated from & Other number & Received from or reference $^{a}$ & $\mathbf{A m p}^{\mathrm{b}}$ \\
\hline \multicolumn{5}{|l|}{ P. agglomerans } \\
\hline Eh220 & Onion, South Africa. & $\begin{array}{l}\text { LMG } 2595 \\
\text { SUH } 1\end{array}$ & M. J. Hattingh; Hattingh and Walters (1981) & - \\
\hline Eh221 & Onion, South Africa. & $\begin{array}{l}\text { LMG } 2596 \\
\text { SUH } 2\end{array}$ & M. J. Hattingh; Hattingh and Walters (1981) & - \\
\hline Eh222 & Onion, South Africa. & SUH 4 & M. J. Hattingh; Hattingh and Walters (1981). & - \\
\hline ATCC 27155 & Knee laceration & & Type strain of $P$. agglomerans & - \\
\hline B46 & Onion, New York & & S. V. Beer & - \\
\hline E37a & Onion, New York & & S. V. Beer & - \\
\hline $\mathrm{J} 14 \mathrm{~b}$ & Onion, New York & & S. V. Beer & - \\
\hline \multicolumn{5}{|l|}{ P. allii } \\
\hline LMG24202 & Onion, Georgia & BD 309; subculture of Hort. Hill 24 & $\begin{array}{l}\text { BCCM; Goszczynska et al. (2006a) and } \\
\text { Brady et al. (2011) }\end{array}$ & - \\
\hline LMG24203 & Onion, South Africa. & BD 377 & BCCM; Brady et al. (2011) & - \\
\hline LMG24248 & Onion, South Africa. & BD 390 & $\begin{array}{l}\text { BCCM; Goszczynska et al. (2006a) and } \\
\text { (Brady et al. 2011) }\end{array}$ & - \\
\hline $\mathrm{J} 12 \mathrm{~b}$ & Onion, New York & & S. V. Beer & - \\
\hline O64c & Onion, New York & & S. V. Beer & - \\
\hline S37a & Onion field soil, New York & & S. V. Beer & - \\
\hline \multicolumn{5}{|l|}{ P. ananatis } \\
\hline LMG20103 & Eucalyptus, South Africa & & ВCCM & + \\
\hline LMG24190 & Onion seed, South Africa & & ВCCM & + \\
\hline LMG24193 & Onion seed, South Africa & & $\mathrm{BCCM}$ & + \\
\hline LMG2665 (type) & Pineapple, Brazil. & ATCC 33244 & $\mathrm{BCCM}$ & + \\
\hline LMG2668 & Pineapple, Hawaii & & $\mathrm{BCCM}$ & + \\
\hline OC $34 b$ & Onion, New York & & Carr et al. (2013) & + \\
\hline OC37 & Onion, New York & & Carr et al. (2013) & + \\
\hline OC42 & Onion, New York & & Carr et al. (2013) & + \\
\hline OC5a & Onion, New York & & Carr et al. (2013) & + \\
\hline B51 & Onion, New York & & S. V. Beer & + \\
\hline D72 & Onion, New York & & S. V. Beer & + \\
\hline I53a & Onion, New York & & S. V. Beer & + \\
\hline $\mathrm{J} 21 \mathrm{~b}$ & Onion, New York & & S. V. Beer & + \\
\hline $\mathrm{J} 32 \mathrm{~b}$ & Onion, New York & & S. V. Beer & + \\
\hline $\mathrm{J} 63 \mathrm{~b}$ & Onion, New York & & S. V. Beer & + \\
\hline $\mathrm{J} 78 \mathrm{~b}$ & Onion, New York & & S. V. Beer & + \\
\hline L32c & Onion, New York & & S. V. Beer & + \\
\hline M46 & Onion, New York & & S. V. Beer & + \\
\hline M8c & Onion, New York & & S. V. Beer & + \\
\hline N5 & Onion, New York & & S. V. Beer & + \\
\hline $\mathrm{N} 8 \mathrm{~b}$ & Onion, New York & & S. V. Beer & + \\
\hline O81b & Onion, New York & & S. V. Beer & + \\
\hline $\mathrm{R} 36 \mathrm{~b}$ & Onion, New York & & S. V. Beer & + \\
\hline $\mathrm{T} 29$ & Onion, New York & & S. V. Beer & + \\
\hline $\mathrm{T} 53 \mathrm{c}$ & Onion, New York & & S. V. Beer & + \\
\hline T85b & Onion, New York & & S. V. Beer & + \\
\hline Pna 97-1 & Onion, Georgia & & R. Gitaitis; Gitaitis et al. (2002) & + \\
\hline A8 & Melon, Japan & & Kido et al. (2010) & + \\
\hline AJiSAi-9701 & Hydrangea, Japan & & Kido et al. (2010) & + \\
\hline CTB1004 & Rice, Japan & & Kido et al. (2010) & + \\
\hline PA-5 & Pineapple, Japan & & Kido et al. (2010) & + \\
\hline SUPP2219 & Rice, Japan & & Kido et al. (2010) & + \\
\hline SWEETCORN-101 & Corn, Japan & & Kido et al. (2010) & + \\
\hline Blackshank 15 & Onion, Georgia & & R. Walcott; Goszczynska et al. (2006b) & + \\
\hline Hort. Hill 31 & Onion, Georgia & & R. Walcott; Goszczynska et al. (2006b) & + \\
\hline BD 622 & Corn, South Africa. & & Brady et al. (2008) & + \\
\hline \multicolumn{5}{|c|}{ P. stewartii subsp. stewartii } \\
\hline DC283 & & & D. Coplin; Dolph et al. (1988) & - \\
\hline \multicolumn{5}{|l|}{ Other Pantoea } \\
\hline Eh282 & Pineapple, Hawaii & M189 & A. M. Alvarez, UH & - \\
\hline L4 & Onion, New York & & S. V. Beer & - \\
\hline L52b & Onion, New York & & S. V. Beer & - \\
\hline $\mathrm{J} 49 \mathrm{a}$ & Onion, New York & & S. V. Beer & - \\
\hline
\end{tabular}

${ }^{a}$ BCCM $=$ BCCM/LMG Bacteria Collection and $\mathrm{UH}=$ University of Hawaii.

b Amplification with PANA_1080 61F/1009R. 
strains and close relatives. An additional set of bacterial strains (Table 4) was used to test the specificity of each primer set against other genera of onion-pathogenic and onion-associated bacteria. A subset of these bacterial pathogens of onion (Table 4) was used to test the performance of the three primer pairs in mixtures of target and nontarget bacteria.

Identification of bacterial strains. Bacterial strains recovered from onion bulbs or onion fields in New York State were identified by amplifying and sequencing a portion of the conserved gyrB gene from pure cultures, as described by Bonasera et al. (2014). Amplicons were purified for sequencing using the Clean and Concentrator-5 kit (Zymo Research Corp., Irvine, CA) and sequenced at the Cornell University Biotechnology Resource Center. Sequencing results were compared with the National Center for Biotechnology Information (NCBI) nucleotide database using blastn. Strains with high percentages of sequence identity to strains identified as $P$. ananatis, Burkholderia spp., or Enterobacter spp. were of interest. For these, gyrB sequences were aligned with sequences from GenBank in the program MegAlign (DNAStar, Madison, WI) using the ClustalW method and visualized as phylogenetic trees in MegAlign. For Enterobacter and Pantoea spp., the gyrB sequences were sufficiently informative to resolve distinct clades for $P$. ananatis, $P$. allii, and $P$. agglomerans as well as a distinct clade for most Enterobacter strains isolated from onion. The clade harboring most Enterobacter strains isolated from onion included EcWSU1 (CP002886.1), a genome-sequenced strain isolated from onion in Colorado, and

Table 3. Strains used to test Enterobacter sp. primers

\begin{tabular}{|c|c|c|c|c|}
\hline Strain & Isolated from & Other number & Received from or reference ${ }^{a}$ & $\mathbf{A m p}^{\mathrm{b}}$ \\
\hline \multicolumn{5}{|l|}{ Clustering $^{\mathrm{c}}$} \\
\hline EcWSU1 & Onion, Colorado; subculture of $\mathrm{O} 310$ & & $\begin{array}{l}\text { Humann et al. (2011); Schroeder et al. } \\
\text { (2010) }\end{array}$ & + \\
\hline $1.1 \mathrm{WA}$ & Onion & 1.1 & B. Schroeder; WSU & + \\
\hline $3.3 \mathrm{WA}$ & Onion & 3.3 & B. Schroeder; WSU & + \\
\hline $4.4 \mathrm{WA}$ & Onion & 4.4 & B. Schroeder; WSU & + \\
\hline $5.5 \mathrm{WA}$ & Onion & 5.5 & B. Schroeder; WSU & + \\
\hline $10.6 \mathrm{WA}$ & Onion & 10.6 & B. Schroeder; WSU & + \\
\hline $11.5 \mathrm{WA}$ & Onion & 11.5 & B. Schroeder; WSU & + \\
\hline $\mathrm{O} 121 \mathrm{CO}$ & Colorado Pathogenic to onion. & O121 & H. Schwartz; CSU & + \\
\hline $\mathrm{O} 144 \mathrm{CO}$ & Colorado Pathogenic to onion. & O144 & H. Schwartz; CSU & + \\
\hline $0174 \mathrm{CO}$ & Infected onion in field. Colorado & O174 & H. Schwartz; CSU & + \\
\hline $\mathrm{O} 280 \mathrm{CO}$ & & $\mathrm{O} 280$ & H. Schwartz; CSU & + \\
\hline $\mathrm{O} 310 \mathrm{CO}$ & Onion, Colorado & O310 & H. Schwartz; CSU & + \\
\hline $\mathrm{O} 325 \mathrm{CO}$ & Colorado Pathogenic to onion. & $\mathrm{O} 325$ & H. Schwartz; CSU & + \\
\hline Ecl1 NY & Onion, New York & Ecl1 & Ali Zaid & + \\
\hline Ecl2 NY & Onion, New York & Ecl2 & Zaid et al. (2012) & + \\
\hline Ecl3 NY & Soil from onion field, New York & Ecl3; ATCC BAA-2271 & Zaid et al. (2011); Zaid et al. (2012) & + \\
\hline Ecl6 NY & Onion, New York & Ec16; ATCC BAA-2272 & Zaid et al. (2011) & + \\
\hline $\mathrm{A} 5 \mathrm{~b}$ & Onion, New York & & S. V. Beer & + \\
\hline A56a & Onion, New York & & S. V. Beer & + \\
\hline $\mathrm{A} 68 \mathrm{~b}$ & Onion, New York & & S. V. Beer & + \\
\hline F38a & Onion, New York & & S. V. Beer & + \\
\hline $\mathrm{H} 29 \mathrm{c}$ & Onion, New York & & S. V. Beer & + \\
\hline I52a & Onion, New York & & S. V. Beer & + \\
\hline J88 & Onion, New York & & S. V. Beer & + \\
\hline K64 & Onion, New York & & S. V. Beer & + \\
\hline L87a & Onion, New York & & S. V. Beer & + \\
\hline \multicolumn{5}{|l|}{ Not clustering ${ }^{\mathrm{d}}$} \\
\hline A10a & Onion, New York & & S. V. Beer & - \\
\hline Ecl4 NY & Onion, New York & Ecl4 & S. V. Beer & - \\
\hline Ecl-1 GA & Onion, Georgia & Ecl-1 & R. Gitaitis, UG & - \\
\hline Ecl-2 GA & Onion, Georgia & Ecl-2 & R. Gitaitis, UG & - \\
\hline Ecl-3 GA & Onion, Georgia & Ecl-3 & R. Gitaitis, UG & - \\
\hline Ecl7 NY & Onion field soil, New York & Ecl7; ATCC BAA-2273 & Zaid et al. (2011) & - \\
\hline FC081213-33 & Creek adjacent to onion field, New York & & S. V. Beer & - \\
\hline M29c & Onion, New York & & S. V. Beer & - \\
\hline \multicolumn{5}{|l|}{ Enterobacter spp. ${ }^{\mathrm{e}}$} \\
\hline Ecl 204/77 & & & CDC; Zaid et al. (2012) & - \\
\hline Ecl 280/77 & & & CDC; Zaid et al. (2012) & - \\
\hline Ecl ATCC 23355 & & & $\begin{array}{l}\text { B. Schroeder, WSU; Zaid et al. } \\
\text { (2012) }\end{array}$ & - \\
\hline Ecl ATCC 13047 & $\begin{array}{l}\text { Isolated from spinal fluid; E. cloacae type } \\
\text { strain }\end{array}$ & & B. Schroeder, WSU. & - \\
\hline ATCC 29941 & & & Zaid et al. (2012) & - \\
\hline \multicolumn{5}{|l|}{ Other species } \\
\hline Klebsiella mobilis 819/56 & & & $\mathrm{CDC}$ & - \\
\hline K. pneumoniae ATCC 15574 & $\begin{array}{l}\text { Germinating seedlings of Psychotria } \\
\text { bacteriophila }\end{array}$ & & & - \\
\hline
\end{tabular}


E. ludwigii EN-119 (JTLO01000001.1) (Li et al. 2015), the type strain for that species (Supplementary Fig. S1). For Burkholderia spp., partial $\operatorname{gyr} B$ sequences designated strains as $B$. gladioli or within the BCC. However, the partial $g y r B$ sequences were unable to sufficiently differentiate BCC species, because published sequences from strains of the same species did not form distinct clades.

Tests of bacterial strains for pathogenicity to onion bulbs. Several strains identified as Burkholderia spp. were assessed for pathogenicity in onion bulbs. Prior to pathogenicity testing, strains were assessed for their ability to grow at $37^{\circ} \mathrm{C}$. Strains similar to B. phymatum did not grow well at $37^{\circ} \mathrm{C}$ but did grow well at $28^{\circ} \mathrm{C}$. Strain O64a grew well at $37^{\circ} \mathrm{C}$. Bacteria were swabbed from LB agar plates into sterile high-purity (HP) water using sterile cotton-tipped applicators. Suspensions were adjusted to an optical density at $600 \mathrm{~nm}\left(\mathrm{OD}_{600 \mathrm{~nm}}\right)=0.25$ or until deemed cloudy visually. Previously autoclaved toothpicks were dipped in bacterial suspensions and stabbed into the sides or shoulders of bulbs. Bulbs were placed in plastic bags to maintain humidity and incubated for 4 days at $37^{\circ} \mathrm{C}$ or 7 days at $28^{\circ} \mathrm{C}$, as deemed appropriate based on temperatures at which tested strains grew well.

Selection of genes for primer design. For Burkholderia spp. primers, genes were selected using the Burkholderia Genome Database (http://www.burkholderia.com/) (Winsor et al. 2008). A comparative search was performed to find genes annotated as "hypothetical protein" present in the genome sequences of strains of BCC bacteria $B$. ambifaria, B. cenocepacia, B. cepacia, B. gladioli, and B. multivorans but absent from strains of $B$. mallei, B. pseudomallei, and B. thailandensis, which do not belong to the BCC and have never been described as onion pathogens, as well as B. vietnamiensis, which falls within the BCC but also is reportedly not pathogenic on onion (Garrity et al. 2005). The resulting list was filtered to eliminate genes that were too short for primer design. Bamb_5978 from B. ambifaria and similar genes from other strains (Bcen_5856, Bcep1808_5498, Bmul_5338, and Bgla_2g16680) were chosen because they are longer than $3 \mathrm{~kb}$, which would facilitate design of compatible primers.

The target gene for $P$. ananatis primers was selected from the chromosome of LMG20103 (CP001875.2) by selecting putative genes greater than 1,000 bp and annotated as encoding hypothetical proteins. These were compared against the NCBI nucleotide collection database via blastn. PANA_1080 was chosen because it was of sufficient length, and the top four matches in the blast search were $P$. ananatis (1,019 to 1,032 identities of $1,032 \mathrm{bp})$, while the fifth best match, to mouse, was poor (42 identities of 1,032 bp).

For Enterobacter sp. primers, chromosomal DNA sequence from Enterobacter strain EcWSU1 (CP002886.1), a strain originally isolated from onion, was compared with sequences from $P$. ananatis
LMG20103 (NC_013956.1) and Klebsiella oxytoca KCTC 1686 (CP003218.1) using progressive Mauve (Mauve version 2.3.1, build 173; Darling et al. 2010). Genes found in EcWSU1 but not the other two bacterial strains were then checked against the NCBI genomes database using blastn. EcWSU1_01990 was selected based on the absence of similarity to genes in other genera but high similarity within EcWSU1, ATCC 13047 (NC_014121.1), and NCTC 9394 (FP929040.1). These strains were all annotated as E. cloacae at the time of primer design.

Primer design and selection. DNA sequences for Bamb_5978, PANA_1080, and EcWSU1_01990 and similar sequences from other bacteria were collected from the NCBI genome database or the Burkholderia Genome Database and aligned separately using MegAlign. Candidate primer sites were chosen from well-conserved regions of the gene alignments. For Burkholderia spp., five forward and five reverse primers were designed based on Bamb_5978. Three forward and three reverse primers were designed based on PANA_1080. For Enterobacter sp., an initial set of EcWSU1_01990-based primers was found to amplify Enterobacter strains too generally. The sequences of amplicons from onion-field samples using this original primer set were thereafter included in additional alignments to refine the specificity of the primers. Eight forward and six reverse primers were designed based on EcWSU1_01990.

For Burkholderia spp. primers, all combinations of five forward and five reverse primers were tested against two strains of $B$. cepacia and one strain of $B$. cenocepacia. The primer pair that gave the highest yields of amplicons without nonspecific amplicons with the three strains (BAMB_5987 40F/350R; Table 5) was investigated further.

For $P$. ananatis primers, all combinations of three forward and three reverse primers for PANA_1080 were tested against $P$. ananatis OC5a. The primer pair that gave the highest yield of amplicons was PANA_1080 61F/1009R (Table 5). For primers intended to amplify the cluster of Enterobacter strains most commonly isolated from onion (Enterobacter sp. primers), 14 primer pair combinations were tested against EcWSU1 and two nontarget strains of Enterobacter as template. Primer pairs amplifying only EcWSU1 then were tested against an additional five nontarget strains of Enterobacter. The primer pair EcWSU1_01990 30F/443R (Table 5) was chosen for further testing because it did not yield nonspecific amplicons in the initial screens.

PCR protocols. Specific PCR primers were assessed against various strains using bacterial cells suspended in water as template. In all, 5 to 10 colonies ranging in size from 0.5 to $2.0 \mathrm{~mm}$ in diameter after growing on LB agar for 1 to 2 days were placed in $200 \mu \mathrm{l}$ of sterile water using sterile wooden applicators.

Table 4. Onion-pathogenic bacteria used to assess BAMB_5978 40F/350R, PANA_1080 61F/1009R, and EcWSU1_01990 30F/443R primer pairs

\begin{tabular}{|c|c|c|c|c|c|c|}
\hline \multirow[b]{2}{*}{ Strain } & \multirow[b]{2}{*}{ Isolated from } & \multirow[b]{2}{*}{$\begin{array}{c}\text { Strain } \\
\text { designations }\end{array}$} & \multirow[b]{2}{*}{ Received from or reference } & \multicolumn{3}{|c|}{ Amplification with } \\
\hline & & & & $\begin{array}{c}\text { BAMB_5978 } \\
\text { 40F/350R }\end{array}$ & $\begin{array}{c}\text { PANA_1080 } \\
\text { 61F/1009R }\end{array}$ & $\begin{array}{c}\text { EcWSU1_01990 } \\
\text { 30F/443R }\end{array}$ \\
\hline Burkholderia cepacia & Onion, 1948 & ATCC 25416 & Type strain of B. cepacia & + & - & - \\
\hline B. gladioli pv. alliicola & Onion bulb rot & ATCC 19302 & & + & - & - \\
\hline Dickeya dadantii & & Dickey 151 & & - & - & - \\
\hline Enterobacter cloacae & Onion & EcWSU1 & & - & - & + \\
\hline Erwinia rhapontici & Rhubarb, England & ATCC 29283 & Type strain of E. rhapontici & - & - & - \\
\hline Pantoea agglomerans & Onion, South Africa. & $\begin{array}{l}\text { LMG 2595; } \\
\text { SUH 1; Eh220 }\end{array}$ & $\begin{array}{l}\text { M. J. Hattingh; Hattingh and } \\
\text { Walters (1981) }\end{array}$ & - & - & - \\
\hline P. agglomerans & Knee laceration & ATCC 27155 & $\begin{array}{l}\text { Type strain of } \\
P . \text { agglomerans }\end{array}$ & - & - & - \\
\hline P. ananatis & Pineapple, Brazil & $\begin{array}{l}\text { ATCC 33244; } \\
\text { LMG } 2665\end{array}$ & Type strain of $P$. ananatis & - & + & - \\
\hline $\begin{array}{l}\text { Pectobacterium carotovorum } \\
\text { subsp. carotovorum }\end{array}$ & Potato, Denmark & ATCC 15713 & & - & - & - \\
\hline Pseudomonas viridiflava & $\begin{array}{l}\text { Dwarf or runner bean, } \\
\text { Switzerland }\end{array}$ & LMG 2352 & & - & - & - \\
\hline Rahnella aquatilis & $\begin{array}{l}\text { Drinking water, } \\
\text { France }\end{array}$ & ATCC 33071 & Type strain of $R$. aquatilis & - & - & - \\
\hline $\begin{array}{l}\text { Xanthomonas axonopodis } \\
\text { pv. allii }\end{array}$ & Onion, Colorado & $\mathrm{O} 274$ & $\begin{array}{l}\text { H. Schwartz; Colorado State } \\
\text { University }\end{array}$ & - & - & - \\
\hline
\end{tabular}


Reactions to test primer specificity were routinely run in $12-\mu 1$ volumes. For sensitivity assays, $25-\mu l$ reaction volumes were used. Reaction compositions and conditions were adjusted for each primer pair accordingly (Tables 6 and 7). The lengths of annealing and elongation steps were adjusted to accommodate thermal cyclers with differing ramp rates.

Gel electrophoresis. Five microliters of each completed reaction were resolved and visualized in 1\% agarose gels (Agarose LF; Amresco, Solon, OH) supplemented with SybrSafe (Life Technologies, Grand Island, NY). Gels were run in $1 \times$ Tris-acetate-EDTA buffer and visualized on a model 3-3000 transilluminator (Fotodyne Inc., Hartland, WI). Amplicon size was estimated by comparison with a DNA ladder (2-log DNA ladder; New England Biolabs, Ipswich, MA).

Determination of primer sensitivity. Sterile cotton-tipped applicators were used to transfer B. cepacia strain ATCC 25416, P. ananatis strain OC5a, and Enterobacter strain EcWSU1 from LB agar plates incubated overnight into autoclaved HP water. Bacterial suspensions were prepared to an $\mathrm{OD}_{600 \mathrm{~nm}}=0.2$. Tenfold serial dilutions were prepared from each bacterial suspension, and suspensions and dilutions were used directly as templates in PCR. Additionally, suspensions and dilutions were spotted onto LB agar, and CFU per milliliter for each suspension was calculated. For our purposes, sensitivity is the order of magnitude of cells that could be amplified consistently in at least two of three repeated assays.
Determination of primer specificity. BAMB_5978 40F/350R primers were screened against $25 \mathrm{BCC}$ strains that were isolated from onion previously and an additional four BCC strains isolated from soil. Additionally, the primers were tested against four B. gladioli strains, an additional 10 strains putatively identified as Burkholderia spp. but falling outside of the BCC and B. gladioli, and six strains from other genera, including Pseudomonas and Xanthomonas (Table 1) and additional onion-pathogenic bacteria (Table 4).

The PANA_1080 61F/1009R primer pair was vetted against more than 36 P. ananatis strains, 18 strains of Pantoea from other species (Table 2), and additional onion-pathogenic bacteria (Table 4).

The EcWSU1_01990 30F/443R primer pair was tested against 26 E. ludwigii-like strains isolated from onion or onion-field soil, an additional four strains of Enterobacter spp. from onion or onion-field environs (strains M29c, Ecl-1 GA, Ecl-2 GA, and Ecl-3 GA could not be placed unambiguously in the genus Enterobacter), five strains of Enterobacter spp. from nonagricultural sources, two strains belonging to the closely related genus Klebsiella (Table 3), and additional onion-pathogenic bacteria (Table 4).

Amplification of each strain was tested in three separate experiments. Failure to amplify a target strain during a repetition of the experiment occurred rarely. Failure of a target strain to amplify was typically accompanied by lack of primer dimers or any background. Primer sets were scored as having detected a strain if an amplicon

Table 5. Polymerase chain reaction primers used in this study

\begin{tabular}{|c|c|c|c|c|}
\hline Primer pairs used & Primer sequence & $\begin{array}{c}\text { Annealing } \\
\text { temperature }\left({ }^{\circ} \mathrm{C}\right)\end{array}$ & $\begin{array}{c}\text { Expected } \\
\text { amplicon size } \\
\text { (bp) }\end{array}$ & Source \\
\hline \multicolumn{5}{|l|}{$\begin{array}{c}\text { Burkholderia gladioli and } \\
\text { some BCC } \text { Species }^{\text {a }}\end{array}$} \\
\hline $\begin{array}{c}\text { BAMB_5978 40F/350R } \\
\text { pair }\end{array}$ & & 55 & 336 & \\
\hline BAMB_5978 40F & 5'-GTA CGG CAA GTT CAC CGA CG-3' & & & This work \\
\hline BAMB_5978 350R & 5'-CCG AAC ATC TGC TCG AAG AA-3' & & & This work \\
\hline \multicolumn{5}{|l|}{$\mathrm{BCC}^{\mathrm{a}}$} \\
\hline BCR $1 / 2$ pair & & 58 & $1,043^{\mathrm{b}}$ & \\
\hline BCR1 & 5'-TGA CCG CCG AGA AGA GCA A-3' & & & $\begin{array}{l}\text { Mahenthiralingam et al. } \\
2000\end{array}$ \\
\hline BCR2 & 5'-CTC TTC TTC GTC CAT CGC CTC-3' & & & $\begin{array}{l}\text { Mahenthiralingam et al. } \\
2000\end{array}$ \\
\hline \multicolumn{5}{|l|}{ Genus Burkholderia } \\
\hline BUR3/4 pair & & 57 & $385^{\mathrm{b}}$ & \\
\hline BUR3 & $5^{\prime}-\mathrm{GA}(\mathrm{AG})$ AAG CAG TTC GGC AA-3' & & & Payne et al. 2005, 2006 \\
\hline BUR4 & 5'-GAG TCG ATG ACG ATC AT-3' & & & Payne et al. 2005, 2006 \\
\hline \multicolumn{5}{|l|}{ Pantoea ananatis } \\
\hline $\begin{array}{l}\text { PANA_1080 61F/1009R } \\
\text { pair }\end{array}$ & & 55 & 949 & \\
\hline PANA_1080 61F & 5'-ACC CTG TCC CCG TTG GCA CTG T-3' & & & This work \\
\hline PANA_1080 1009R & 5'-AAT GAT GCC CAC TGT TGA AGG AAT-3' & & & This work \\
\hline PanITS1/EC5 pair & & 51 & $398^{\mathrm{b}}$ & \\
\hline PanITS1 & 5'-GTC TGA TAG AAA GAT AAA GAC-3' & & & Gitaitis et al. 2002 \\
\hline EC5 & $5^{\prime}$-TGC CAG GGC ATC CAC CG-3' & & & Gitaitis et al. 2002 \\
\hline PanITS1/EC5 pair & & 51 & $398^{\mathrm{b}}$ & \\
\hline PanITS1 & 5'-GTC TGA TAG AAA GAT AAA GAC-3' & & & $\begin{array}{l}\text { Carr et al. 2010, Gitaitis } \\
\text { et al. } 2002\end{array}$ \\
\hline $\mathrm{AS} 2 \mathrm{~b}$ & 5'-TTC ATA TCA CCT TAC CGG CGC-3' & & & Carr et al. 2010 \\
\hline PanITS1/EC5 pair & & 60 & 361 or $389^{b}$ & \\
\hline EC5 Figueiredo & 5'-TGC CAG GGC ATC CAC CGT GTA CGC T-3' & & & $\begin{array}{l}\text { Figueiredo and Paccola- } \\
\text { Meirelles, } 2012\end{array}$ \\
\hline ANAF & 5'-CGT GAA ACT ACC CGT GTC TGT TGC-3' & & & $\begin{array}{l}\text { Figueiredo and Paccola- } \\
\text { Meirelles, } 2012\end{array}$ \\
\hline \multicolumn{5}{|l|}{ Enterobacter sp. } \\
\hline $\begin{array}{l}\text { EcWSU1_01990 } \\
\text { 30F/443R pair }\end{array}$ & & 55 & 414 & \\
\hline EcWSU1_01990 30F & 5'-GGC AAA GCT CAA CCC GGA GGT ATT CT-3' & & & This work \\
\hline EcWSU1_01990 443R & 5'-CAA AGA AAG ATA ATA ATT TCA CGG TTA GTC-3' & & & This work \\
\hline
\end{tabular}

a $\mathrm{BCC}=$ Burkholderia cepacia complex.

b Amplicon sizes as reported inoriginal references. 
was produced in at least two of three reactions. Strains counted as negative did not amplify in any of the three repetitions of the experiment.

Amplification of target bacteria in mixtures. Bacterial suspensions were prepared by transferring bacteria from LB agar plates into sterile HP water using sterile cotton-tipped applicators. Concentrations were adjusted to $\mathrm{OD}_{600 \mathrm{~nm}}=0.2$. For use as PCR templates, these suspensions were diluted 10-fold in sterile HP water. Mixtures of bacteria were created by mixing suspensions of target bacteria with one or two strains of nontarget bacteria, with each strain in the mixture diluted 10-fold from the suspensions at $\mathrm{OD}_{600 \mathrm{~nm}}=0.2$. Bacteria used in this assay were B. cepacia ATCC 25416, Dickeya dadantii Dickey 151, Enterobacter sp. EcWSU1, P. agglomerans SUH 1, $P$. ananatis ATCC 33244, Pectobacterium carotovorum ATCC 15713, and Pseudomonas viridiflava LMG 2352. Target bacteria were B. cepacia ATCC 25416 for BAMB_5978 40F/350R primers, Pantoea ananatis ATCC 33244 for PANA_1080 61F/1009R primers, and Enterobacter sp. EcWSU1 for EcWSU1_01990 30F/443R primers.

\section{Results}

Comparison of Burkholderia spp. and $\boldsymbol{P}$. ananatis primer sets. DNA from bacterial suspensions of six strains of Burkholderia spp. were used as templates for the BAMB_5978 40F/350R primer pair; Bur3/4 primer pair, which produces amplicons from Burkholderia spp. DNA generally; and BCR1/2, which produces amplicons from DNA of members of the BCC. BAMB_5978 40F/350R amplified DNA from strains in the $\mathrm{BCC}$ and $B$. gladioli. Bur3/4 produced amplicons from DNA from all Burkholderia strains tested, and BCR $1 / 2$ produced amplicons only from DNA from the BCC strains tested, consistent with the specificities reported in the literature (Fig. 1).

Bacterial suspensions of six strains of Pantoea spp., one strain of $P$. stewartii subsp. stewartii, two of $P$. agglomerans, two of $P$. allii, and one $P$. ananatis were used as templates against the PANA_1080 61F/1009R, ANAF/EC5 (Figueiredo and PaccolaMeirelles 2012), PanITS1/EC5 (Gitaitis et al. 2002), and PanITS1/AS2b (Carr et al. 2010) primer pairs to demonstrate differences in primer specificity (Fig. 2). The PANA_1080 61F/1009R primer pair produced an amplicon only from the $P$. ananatis strain. ANAF/EC5 produced amplicons from the $P$. stewartii, $P$. allii, and $P$. ananatis strains. PanITS1/EC5 and PanITS1/AS2b produced amplicons from $P$. allii and $P$. ananatis strains.

Primer specificity. The Burkholderia spp.-specific primers were tested against 29 strains of Burkholderia from the BCC (including

Table 6. Polymerase chain reaction compositions used in this study ${ }^{a}$

\begin{tabular}{ll}
\hline Reagents used & Final concentration \\
\hline 5x OneTaq GC Reaction Buffer & $1 \times$ \\
dNTPs & $0.25 \mathrm{mM}$ \\
Primer 1 & $0.52 \mu \mathrm{M}$ \\
Primer 2 & $0.52 \mu \mathrm{M}$ \\
OneTaq & 0.3 units $/ 12 \mu 1$ reaction \\
Template & $2 \mu \mathrm{l}$ \\
Water & To volume
\end{tabular}

${ }^{a}$ Standard composition was used for all reactions. Reaction volumes were 12 or $25 \mu \mathrm{l}$.
25 strains from onion, 1 of which is the type strain of $B$. cepacia) and 4 strains of $B$. gladioli. These strains yielded positive reactions with the primers. An additional 10 strains identified as Burkholderia spp. but, falling outside of the BCC and B. gladioli, did not amplify with the primers. All of these strains were isolated from onion but, for nine, their gyrB sequences placed them closer to $B$. phymatum than to the BCC or B. gladioli, and these strains did not cause disease in onion in our pathogenicity tests (Supplementary Fig. S2). The primers also failed to amplify other closely related bacteria often associated with onion such as Xanthomonas axonopodis and several fluorescent pseudomonads (Table 1) and other non-Burkholderia onion pathogens tested (Table 4).

The $P$. ananatis primers amplified 36 strains of $P$. ananatis, including 21 strains isolated from onion grown in New York and several other strains that originated elsewhere. The primers failed to amplify strains of $P$. allii, a closely related species reported to cause disease in onion. The primers also failed to amplify the P. agglomerans strains tested, which included both pathogenic and nonpathogenic strains (Table 2).

The Enterobacter sp. primers produced an amplicon of the appropriate size for all 26 strains that clustered with EcWSU1 and $E$. ludwigii, based on their gyrB sequences. The primers failed to amplify DNA from all other strains tested, including two Enterobacter spp. strains and four strains closely related to Enterobacter, all isolated from onion; two Enterobacter spp. strains isolated from onionfield soil or water; five Enterobacter strains from other sources; and two strains of the closely related genus Klebsiella (Table 3).

Additionally, BAMB_5978 40F/350R, PANA_1080 61F/1009R, and EcWSU1_0199030F/443R were tested against 13 strains of species that are pathogenic to onion or are frequently found associated with onion from nine genera (Table 4). Primers were found to specifically amplify DNA from target bacteria when other bacteria were present that might also be found in diseased onion bulbs (Fig. 3).

Primer sensitivity. For each primer set (BCC- and B. gladiolispecific primers BAMB_5978 40F/350R, P. ananatis-specific primers PANA_1080 61F/1009R, and Enterobacter sp. primers EcWSU1_01990 30F/443R), the minimum number of CFU detectable per $25-\mu 1$ reaction mixture was approximately $10^{3}$. The OneTaq Standard Reaction Buffer and OneTaq GC Reaction Buffer were tested with the EcWSU1_01990 30F/443R primer pair to compare sensitivity and specificity. Primer specificity was similar with both buffers but sensitivity assays with bacterial suspensions as templates were more consistent and, on average, more sensitive using the GC Reaction Buffer.

Use of primers with mixed bacterial cultures. BAMB_5978 40F/350R, PANA_1080 61F/1009R, and EcWSU1_01990 30F/ $443 \mathrm{R}$ primer pairs were tested against pure cultures of a single bacterial strain and against mixtures containing an appropriate target strain and an additional one or two strains of nontarget bacteria. In each case, primer sets detected the target strains singly or in the presence of one or two other bacteria (Fig. 4).

\section{Discussion}

To design specific primers, we used genome sequences available in GenBank and other public databases to identify genes present in the bacteria we wished to detect but generally absent from nontarget

Table 7. Cycling conditions used in this studya

\begin{tabular}{|c|c|c|c|c|c|c|c|}
\hline Conditions $^{\mathbf{b}}$ & $\begin{array}{c}\text { EcWSUl_01990 } \\
\text { 30F/443R }\end{array}$ & $\begin{array}{c}\text { BAMB_5978 } \\
\text { 40F/350 R } \\
\end{array}$ & $\begin{array}{c}\text { PANA_1080 } \\
\text { 61F/1009R }\end{array}$ & BCR1/2 & BUR3/4 & $\begin{array}{c}\text { ANAF/EC5 } \\
\text { Figueiredo }\end{array}$ & $\begin{array}{c}\text { Pan ITS1/EC5 and } \\
\text { PanITSI/AS2b }\end{array}$ \\
\hline $\begin{array}{l}\text { Annealing } \\
\left({ }^{\circ} \mathrm{C}\right)\end{array}$ & 55 & 55 & 55 & 58 & 57 & 60 & 51 \\
\hline Extension & $45 \mathrm{~s}$ to $1 \min 10 \mathrm{~s}$ & $40 \mathrm{~s}$ & $45 \mathrm{~s}$ to $1 \min 15 \mathrm{~s}$ & $70 \mathrm{~s}$ & $45 \mathrm{~s}$ & 30 to $45 \mathrm{~s}$ & 30 to $45 \mathrm{~s}$ \\
\hline $\begin{array}{l}\text { Steps } \\
\text { repeated }\end{array}$ & 45 & 45 & 45 & 30 & 30 & 30 & 30 \\
\hline
\end{tabular}

\footnotetext{
${ }^{a}$ Parameters are listed for each primer pair. Duration of steps 3 and steps 4 was adjusted to accommodate thermal cyclers with differing ramp speeds.

${ }^{\mathrm{b}}$ Generic cycling parameters were standard, with three variable parameters: annealing temperatures, extension time, and the number of times steps 2 through 4 were repeated in total. Step $1: 95^{\circ} \mathrm{C}$ for $10 \mathrm{~min}$, step $2: 95^{\circ} \mathrm{C}$ for $30 \mathrm{~s}$, step 3: annealing temperature for 30 to $45 \mathrm{~s}$, step $4:$ extension time at $72^{\circ} \mathrm{C}$, step $5: 72^{\circ} \mathrm{C}$ for
} $10 \mathrm{~min}$, and step 6: hold at $12^{\circ} \mathrm{C}$. 
bacteria. This strategy was intended to make false positives unlikely because nontarget bacteria would completely lack the gene containing the primer pair's annealing sites. For each primer pair designed, we paid little attention to the putative function of the gene on which the sequence of the primer pairs were based. However, without a clear understanding of the target gene's role or the phenotypic consequences of its mutation or loss, it is possible to choose a priming site that might be altered or deleted with little fitness cost. Under such circumstances, one might find populations of the target organism that are not amplifiable, yielding false negative results. To reduce that possibility, we did extensive empirical testing of the new primer sets with many strains. For the three groups of target bacteria we addressed, the novel primer pairs designed proved highly effective and specific for their respective target bacteria.
For the genus Burkholderia, particularly members of the BCC, species continue to be delineated and the genus has changed substantially over the last two decades (Vandamme and Peeters 2014). Numerous primer sets for detecting various bacteria of the genus Burkholderia exist but the intended specificities of these primers differ from the specificity of the BAMB_5978 primer pair we report here. BAMB_5978 primers were designed to amplify B. gladioli and those BCC species likely to be pathogenic to onion. The candidate primer pairs were vetted against numerous Burkholderia strains isolated from onion. The Burkholderia spp.-specific primers amplified all strains isolated from onion that were identified as belonging to the BCC or B. gladioli. They failed to amplify nine nontarget isolates from onion bulbs identified as Burkholderia spp. based on their gyrB sequence. The sequence of $g y r B$ placed these strains as more

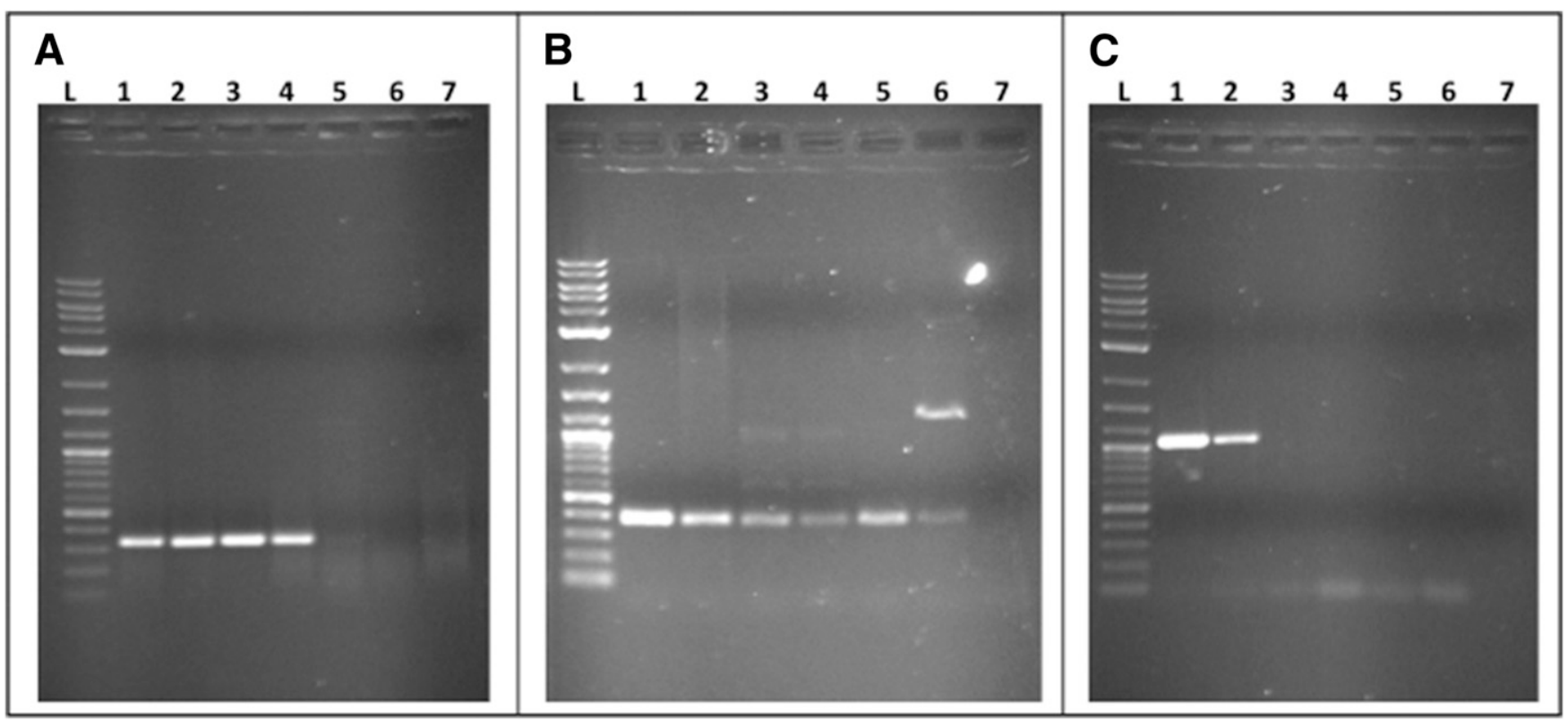

Fig. 1. Primer pair BAMB_5978 amplifies representatives of the Burkholderia cepacia complex and B. gladioli. Three different primer pairs were tested using bacterial suspensions of B. cepacia, B. gladioli, other Burkholderia spp., or water as template. A, BAMB_5978 40F/350R primer pair; B, BUR3/4 primer pair (Payne et al. 2005); and C, BCR1/2 primer pair (Mahenthiralingam et al. 2000). Lane 1, B. cepacia ATCC 25416 (type strain); lane 2, B. cepacia ATCC 39277; lane 3, B. gladioli ATCC 19302; lane 4, B. gladioli PA-23; lane 5, Burkholderia sp. H49a; lane 6, Burkholderia sp. 064a; and lane 7, water. Lanes designated "L" were loaded with 2-log DNA ladder (New England Biolabs).

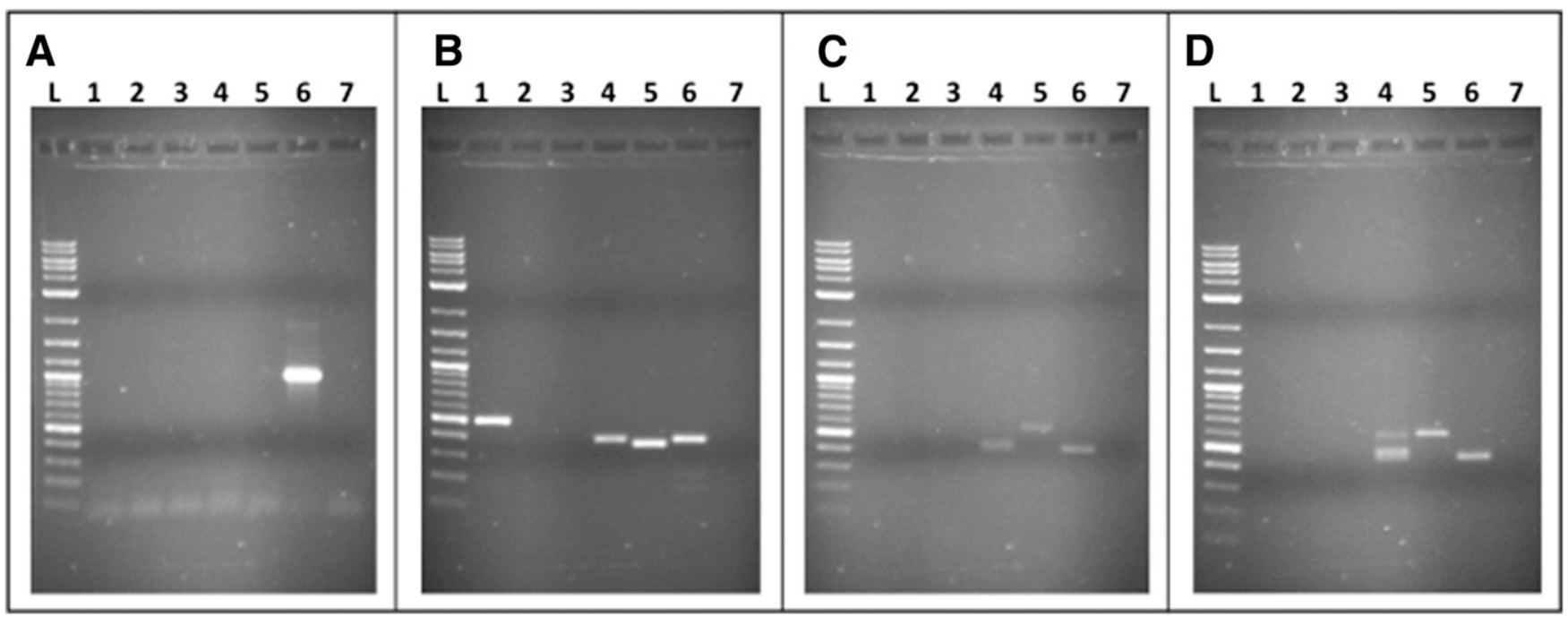

Fig. 2. Primer pair PANA_1080 61F/1009R amplifies Pantoea ananatis specifically. Four different primer pairs were tested using bacterial suspensions of three different Pantoea spp. or water as template. A, PANA_1080 61F/1009R primer pair; B, ANAF/EC5 (Figueiredo and Paccola-Meirelles 2012); C, PanITS1/EC5 (Gitaitis et al. 2002); and D, PanlTS1/AS2b (Carr et al. 2010). Lane 1. P. stewartii subsp. stewartii DC283; lane 2, P. agglomerans ATCC 27155; lane 3, P. agglomerans SUH1; lane 4, P. allii LMG 24202; lane 5, P. allii LMG 24248; lane 6, P. ananatis Pna97-1; and lane 7, water. Lanes designated "L" were loaded with 2-log DNA ladder (New England Biolabs). 
closely related to $B$. phymatum and B. bryophila than to BCC strains or B. gladioli. Work by other groups using the $16 \mathrm{~S}$ ribosomal DNA sequence and multilocus sequence analysis (MLSA) demonstrated that $B$. phymatum and $B$. bryophila reside in a distinct clade within the genus Burkholderia that is separate from the BCC and B. gladioli (Estrada-de los Santos et al. 2013). We are unaware of any reports that strains from this clade cause disease in onion. In our pathogenicity tests in onion bulbs, the tested strains did not cause symptoms.

Onion plants are susceptible to diseases caused by $P$. ananatis and its close relatives $P$. allii and $P$. agglomerans, pathogenic strains of which all cause similar symptoms. The PANA_1080 61F/1009R primer pair was tested against numerous strains of the genus Pantoea, including many $P$. ananatis and $P$. agglomerans strains isolated from onion. The primers consistently amplified strains of $P$. ananatis but not other species of Pantoea, suggesting that the primer pair is sufficiently specific to selectively detect $P$. ananatis. To demonstrate the differing specificities of PANA_1080 61F/1009R and previously published primers for detection of $P$. ananatis, several primer sets were tested against six strains of Pantoea, including one P. stewartii, two $P$. agglomerans, two $P$. allii, and one $P$. ananatis strain. In our hands, the PanITS1/EC5, PanITS1/AS2b, and ANAF/EC5 primer pairs all produced amplicons from the $P$. ananatis strain and two $P$. allii strains tested. Additionally, ANAF/EC5 but not PanITS1/EC5 or PanITS1/AS2b produced an amplicon with $P$. stewartii subsp. stewartii DC283. The amplification of $P$. allii strains was consistent with the specificity of ANAF/EC5 reported previously (Figueiredo and PaccolaMeirelles 2012) and was not reported previously for PanITS1/EC5 (Gitaitis et al. 2002) or PanITS1/AS2b (Carr et al. 2010) because the primers were described prior to the publication of $P$. allii as a species (Brady et al. 2011). Detection of $P$. ananatis and $P$. allii together may be desirable in some cases but, in cases where it is not, PANA_1080 $61 \mathrm{~F} / 1009 \mathrm{R}$ is more discriminatory. The amplification of $P$. stewartii subsp. stewartii DC283 by the ANAF/EC5 primer pair but not PanITS1/EC5 or PanITS1/AS2b was unexpected, because amplification of $P$. stewartii strains was previously noted for PanITS1/EC5 (Gitaitis et al. 2002) but not for ANAF/EC5 (Figueiredo and PaccolaMeirelles 2012). This discrepancy may be due to the fact that the strain of $P$. stewartii used in our assay differed from those used in the original publications. None of the primer sets assessed produced amplicons from $P$. agglomerans strains, which is consistent with published data.

The state of the genus Enterobacter initially proved to be problematic for primer design. The genus was not monophyletic and the use of common biochemical tests for identification of strains often led to misidentification (Kämpfer et al. 2008). It became clear that it was not possible to rely on the accurate identification of genomesequenced strains for a genus in which common identification methods were unreliable and relationships among species unclear. Based on recent MLSA of many strains that represent several species of Enterobacter, Brady et al. (2013) proposed changes to the genus. How the recommended changes and the availability of MLSA data for numerous strains will affect the taxonomic position of the sequenced Enterobacter strains in GenBank is in question. Because the identification of Enterobacter strains in GenBank is not always reliable, we relied on a sequence that we obtained directly from Enterobacter strains isolated from onion to inform our decisions about which strains would be most useful for detection. We found that most strains isolated from onion had very similar partial $\mathrm{gyr} B \mathrm{se}$ quences, and we used this sequence to identify strains with publicly available genome sequence that were likely closely related to our strains of interest. When tested against numerous Enterobacter strains, the EcWSU1_01990 primer set amplified only Enterobacter strains that clustered together based on $\operatorname{gyr} B$ sequence.

The new primer pairs have been tested against numerous bacterial strains and appear to be highly specific for their intended target bacteria. However, the primers are not exceedingly sensitive, requiring $10^{3} \mathrm{CFU}$ per $25 \mu \mathrm{l}$ of reaction mixture. In protocols including a culturing step in order to separate bacteria from sample substrates containing PCR inhibitors, such as onion bulb tissue or high-organic matter muck-land soil, typically used for growth of onion in New York, the required number of bacteria are easily obtained. However, the low sensitivity of our primer assays may limit the utility of these primers in protocols lacking a culturing step.

The primers reported herein have proven useful for detection of the three groups of onion pathogens common in New York State. However, regardless of the geographic region from which they were

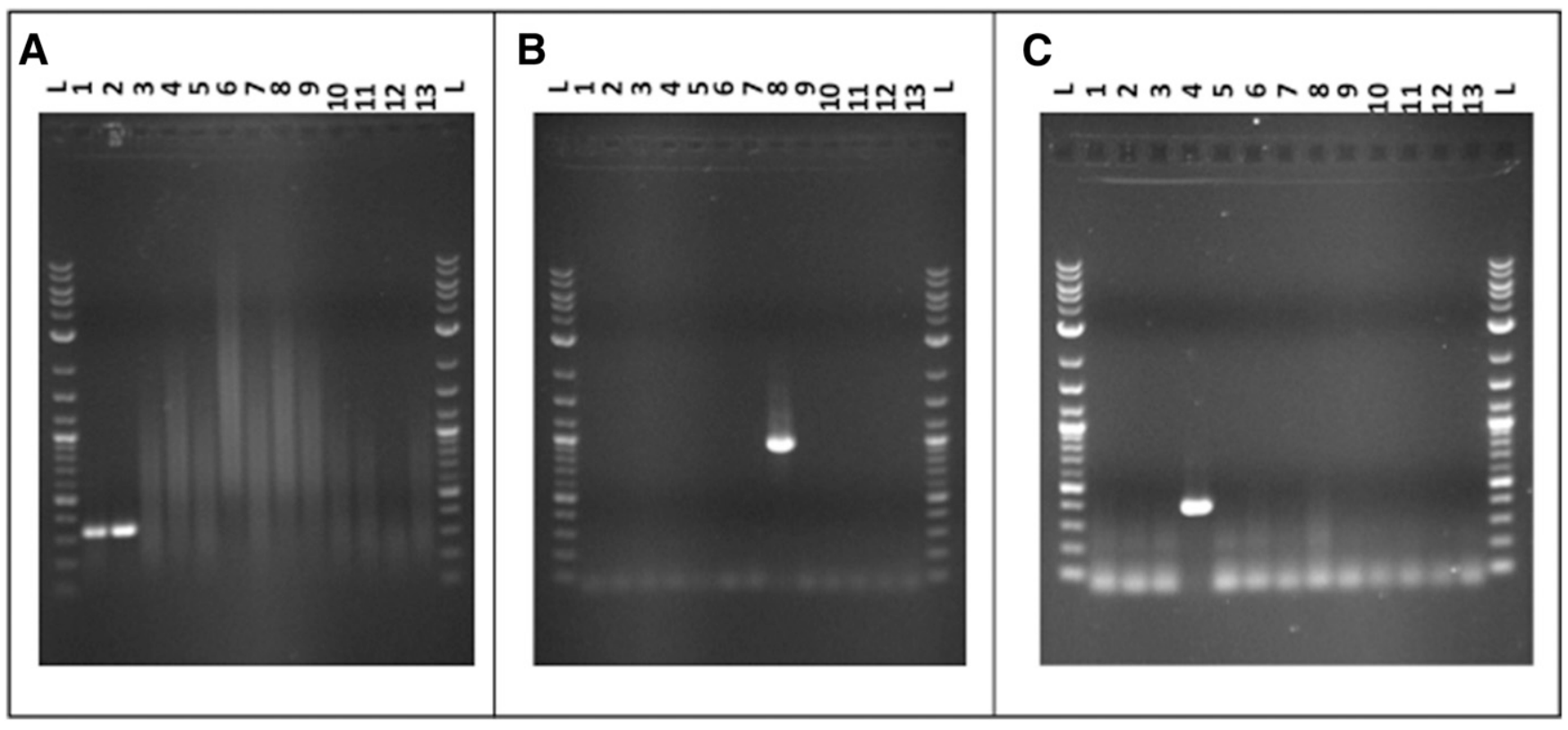

Fig. 3. Primer pairs for specifically detecting Burkholderia strains, including onion pathogens, Pantoea ananatis, or the group of Enterobacter strains most commonly isolated from onion that amplify their target bacteria specifically. Primer pairs were tested against bacterial suspensions or water as templates. A, BAMB_5978 40F/350R primer pair; B, PANA_1080 61F/1009R primer pair; and C, EcWSU1_01990 30F/443R primer pair. Lane 1, Burkholderia cepacia ATCC 25416 (type strain); lane 2, B. gladioli pv. alliicola ATCC 19302; lane 3, Dickeya dadantii Dickey 151; lane 4, Enterobacter sp. EcWSU1; lane 5, Erwinia rhapontici ATCC 29283; lane 6, P. agglomerans SUH1; lane 7, P. agglomerans ATCC 27155; lane 8, P. ananatis ATCC 33244; lane 9, Pectobacterium carotovorum ATCC 15713; lane 10, Pseudomonas viridiflava LMG 2352; lane 11, Rahnella aquatilis ATCC 33071; lane 12, Xanthomonas axonopodis pv. allii 0274; and lane 13, water. Lanes designated "L" were loaded with 2-log DNA ladder (New England Biolabs). 


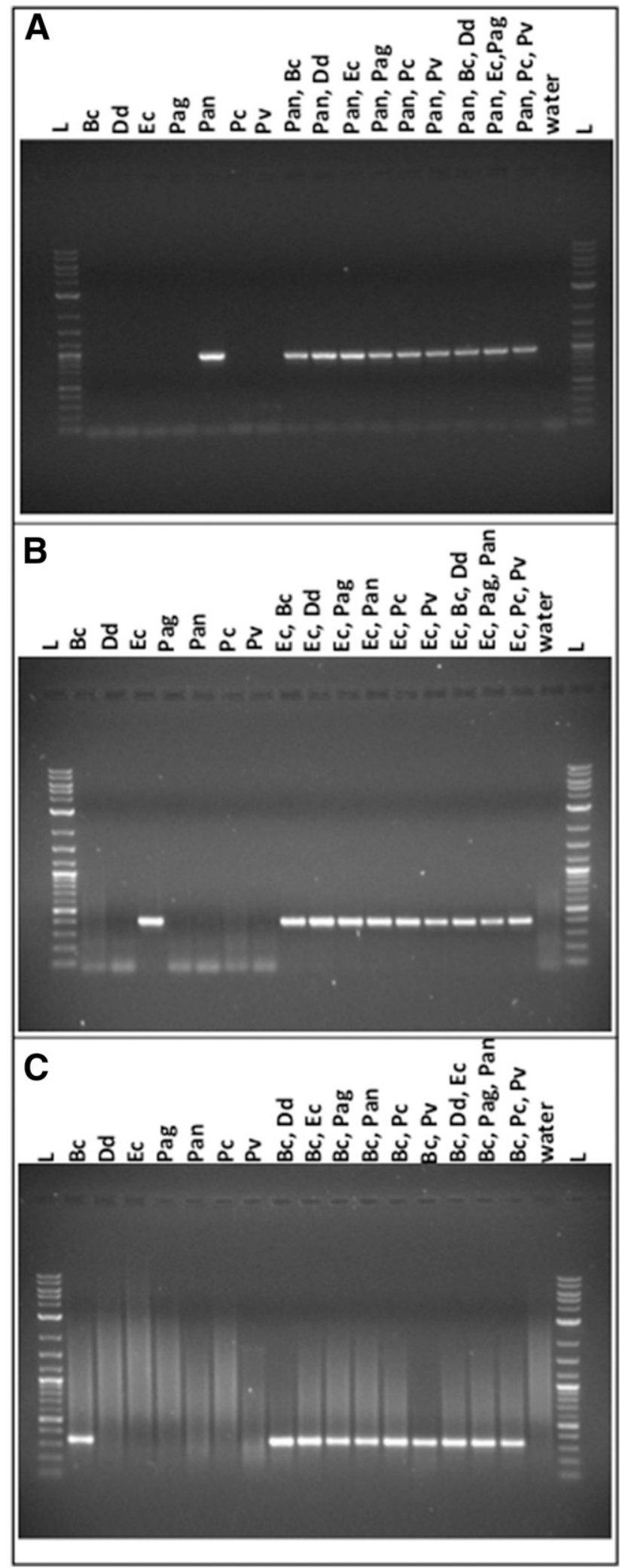

Fig. 4. Primer pairs A, PANA_1080 61F/1009R; B, EcWSU1_01990 30F/443R; and C, BAMB_5978 40F/350R amplify from target bacteria using pure or mixed bacterial suspensions as templates. Polymerase chain reactions (PCR) or ladder $(5 \mu l)$ were loaded into each well. PCR are designated by the bacterial strains used as templates. $\mathrm{L}=2$ - $\log$ ladder (New England Biolabs), $\mathrm{Bc}=$ Burkholderia cepacia ATCC 25416, Dd = Dickeya dadantii Dickey 151, Ec = Enterobacter cloacae EcWSU1, Pag $=$ Pantoea agglomerans ATCC 27155, Pan $=P$. ananatis ATCC 33244, $\mathrm{PC}=$ Pectobacterium carotovorum ATCC 15713, and Pv = Pseudomonas viridiflava LMG 2352. isolated, target strains included in assays of primer specificity were successfully amplified. Our primer pairs, which target single-copy genes and produce discrete, qualitative results, have been assessed specifically for use in detecting pathogens of onion. Thus far, they have proven to be highly specific, each giving few false-negative and no false-positive results. Because primer sets are specific, the primers can be used for mixed cultures or environmental samples, assuming that the bacterial titers are sufficient and inhibition of the PCR is not a problem.

The design and validation of these three primer sets for detection of species of onion-pathogenic bacteria should prove useful for labs investigating bacterial decays of onion bulbs. We leveraged the availability of numerous bacterial genomes in public databases to identify genes present in certain bacteria but absent from the genomes of nontarget bacteria that occupy the same or similar niches. For this primer design strategy to succeed, numerous sequenced genomes of both target bacteria and taxonomically or ecologically related bacteria were required for analysis. Such an approach would not have been possible even 10 years ago. The strategy may have utility for design of primers for other target bacteria of clinical, agricultural, or environmental significance.

\section{Acknowledgments}

Funding in support of this study was provided to S. V. Beer by New York State Specialty Crops Block Grants; a Northeast Regional IPM grant to B. Gugino (Pennsylvania State University) and C. A. Hoepting (Cornell Cooperative Extension, Albion, NY); the United States Department of Agriculture Multi-State Regional Hatch Project W-2008 for research on Iris yellow spot virus, thrips, and other diseases of onion; the New York State Onion Research and Development Program; and Cornell University. We thank onion growers in New York State for gifts of symptomatic onion bulbs from which many pathogens included in these studies were isolated; R. Gitaitis, B. Schroeder, and H. Schwartz for the kind gifts of strains used in panels to determine primer specificity; and B. Schroeder for disclosing unpublished results.

\section{Literature Cited}

Bishop, A. L., and Davis, R. M. 1990. Internal decay of onions caused by Enterobacter cloacae. Plant Dis. 74:692-694.

Bonasera, J. M., Asselin, J. E., and Beer, S. V. 2014. Identification of bacteria pathogenic to or associated with onion (Allium cepa) based on sequence differences in a portion of the conserved gyrase B gene. J. Microbiol. Methods 103:138-143.

Brady, C., Cleenwerck, I., Venter, S., Coutinho, T., and De Vos, P. 2013 Taxonomic evaluation of the genus Enterobacter based on multilocus sequence analysis (MLSA): Proposal to reclassify E. nimipressuralis and E. amnigenus into Lelliottia gen. nov. as Lelliottia nimipressuralis comb. nov. and Lelliottia amnigena comb. nov., respectively, E. gergoviae and E. pyrinus into Pluralibacter gen. nov. as Pluralibacter gergoviae comb. nov. and Pluralibacter pyrinus comb. nov., respectively, E. cowanii, E. radicincitans, E. oryzae and E. arachidis into Kosakonia gen. nov. as Kosakonia cowanii comb. nov., Kosakonia radicincitans comb. nov., Kosakonia oryzae comb. nov. and Kosakonia arachidis comb. nov., respectively, and E. turicensis, E. helveticus and E. pulveris into Cronobacter as Cronobacter zurichensis nom. nov., Cronobacter helveticus comb. nov. and Cronobacter pulveris comb. nov., respectively, and emended description of the genera Enterobacter and Cronobacter. Syst. Appl. Microbiol. 36 309-319.

Brady, C., Cleenwerck, I., Venter, S., Vancanneyt, M., Swings, J., and Coutinho, T. 2008. Phylogeny and identification of Pantoea species associated with plants, humans and the natural environment based on multilocus sequence analysis (MLSA). Syst. Appl. Microbiol. 31:447-460.

Brady, C. L., Goszczynska, T., Venter, S. N., Cleenwerck, I., Vos, P. d., Gitaitis, R. D., Coutinho, T. A., and de Vos, P. 2011. Pantoea allii sp. nov., isolated from onion plants and seed. Int. J. Syst. Evol. Microbiol. 61:932-937.

Burkholder, W. H. 1942. Three bacterial plant pathogens: Phytomonas caryophylli sp. n., Phytomonas alliicola sp. n., and Phytomonas manihotis (ArthaudBerthet et Bondar) Viegas. Phytopathology 32:141-149.

Burkholder, W. H. 1950. Sour skin, a bacterial rot of onion bulbs. Phytopathology 40:115-117.

Carr, E. A., Bonasera, J. M., Zaid, A. M., Lorbeer, J. W., and Beer, S. V. 2010. First report of bulb disease of onion caused by Pantoea ananatis in New York. Plant Dis. $94: 916$.

Carr, E. A., Zaid, A. M., Bonasera, J. M., Lorbeer, J. W., and Beer, S. V. 2013 Infection of onion leaves by Pantoea ananatis leads to bulb infection. Plant Dis. 97:1524-1528.

Darling, A. E., Mau, B., and Perna, N. T. 2010. Progressive Mauve: Multiple genome alignment with gene gain, loss and rearrangement. PLoS One 5: e11147. 
De Smet, B., Mayo, M., Peeters, C., Zlosnik, J. E. A., Spilker, T., Hird, T. J., LiPuma, J. J., Kidd, T. J., Kaestli, M., Ginther, J. L., Wagner, D. M., Keim, P., Bell, S. C., Jacobs, J. A., Currie, B. J., and Vandamme, P. 2015. Burkholderia stagnalis sp. nov. and Burkholderia territorii sp. nov., two novel Burkholderia cepacia complex species from environmental and human sources. Int. J. Syst. Evol. Microbiol. 65:2265-2271.

Dolph, P. J., Majerczak, D. R., and Coplin, D. L. 1988. Characterization of a gene cluster for exopolysaccharide biosynthesis and virulence in Erwinia stewartii. J. Bacteriol. 170:865-871.

Estrada-de los Santos, P., Vinuesa, P., Martínez-Aguilar, L., Hirsch, A. M., and Caballero-Mellado, J. 2013. Phylogenetic analysis of Burkholderia species by multilocus sequence analysis. Curr. Microbiol. 67:51-60.

Figueiredo, J. E. F., and Paccola-Meirelles, L. D. 2012. Short communication: Simple, rapid and accurate PCR-based detection of Pantoea ananatis in maize, sorghum and Digitaria sp. J. Plant Pathol. 94:663-667.

Garrity, G. M., Bell, J. A., and Lilburn, T. 2005. Class II. Betaproteobacteria class. nov. Pages 575-922 in: Bergey's Manual of Systematic Bacteriology, Vol. 2, part C, The Proteobacteria. Brenner, D. J., Krieg, N. R., and Staley, J. T., eds. Springer, New York.

Gitaitis, R., Walcott, R., Culpepper, S., Sanders, H., Zolobowska, L., and Langston, D. 2002. Recovery of Pantoea ananatis, causal agent of center rot of onion, from weeds and crops in Georgia, USA. Crop Prot. 21:983-989.

Goszczynska, T., Moloto, V. M., Venter, S. N., and Coutinho, T. A. 2006a. Isolation and identification of Pantoea ananatis from onion seed in South Africa. Seed Science Technol. 34:655-668.

Goszczynska, T., Venter, S. N., and Coutinho, T. A. 2006b. PA 20, a semiselective medium for isolation and enumeration of Pantoea ananatis. J. Microbiol. Methods 64:225-231.

Hattingh, M. J., and Walters, D. F. 1981. Stalk and leaf necrosis of onion caused by Erwinia herbicola. Plant Dis. 65:615-618.

Humann, J. L., Wildung, M., Cheng, C. H., Lee, T., Stewart, J. E., Drew, J. C., Triplett, E. W., Main, D., and Schroeder, B. K. 2011. Complete genome of the onion pathogen Enterobacter cloacae EcWSU1. Stand. Genomic Sci. 5:279-286.

Kämpfer, P., Nienhüser, A., Packroff, G., Wernicke, F., Mehling, A., Nixdorf, K., Fiedler, S., Kolauch, C., and Esser, M. 2008. Molecular identification of coliform bacteria isolated from drinking water reservoirs with traditional methods and the Colilert-18 system. Int. J. Hyg. Environ. Health 211:374-384.

Kido, K., Hasegawa, M., Matsumoto, H., Kobayashi, M., and Takikawa, Y. 2010. Pantoea ananatis strains are differentiated into three groups based on reactions of tobacco and Welsh onion and on genetic characteristics. J. Gen. Plant Pathol. 76:208-218.

Li, G., Hu, Z., Zeng, P., Bing, Z., and Wu, L. 2015. Whole genome sequence of Enterobacter ludwigii type strain EN-119 ${ }^{\mathrm{T}}$, isolated from clinical specimens. FEMS Microbiol. Lett. 362:fnv033.

Mahenthiralingam, E., Bischof, J., Byrne, S. K., Radomski, C., Davies, J. E., Av-Gay, Y., and Vandamme, P. 2000. DNA-Based diagnostic approaches for identification of Burkholderia cepacia complex, Burkholderia vietnamiensis, Burkholderia multivorans, Burkholderia stabilis, and Burkholderia cepacia genomovars I and III. J. Clin. Microbiol. 38:3165-3173.

Payne, G. W., Ramette, A., Rose, H. L., Weightman, A. J., Jones, T. H., Tiedje, J. M., and Mahenthiralingam, E. 2006. Application of a recA gene-based identification approach to the maize rhizosphere reveals novel diversity in Burkholderia species. FEMS Microbiol. Lett. 259:126-132.

Payne, G. W., Vandamme, P., Morgan, S. H., LiPuma, J. J., Coenye, T., Weightman, A. J., Jones, T. H., and Mahenthiralingam, E. 2005. Development of a recA gene-based identification approach for the entire Burkholderia genus. Appl. Environ. Microbiol. 71:3917-3927.

Peeters, C., Zlosnik, J. E., Spilker, T., Hird, T. J., LiPuma, J. J., and Vandamme, P. 2013. Burkholderia pseudomultivorans sp. nov., a novel Burkholderia cepacia complex species from human respiratory samples and the rhizosphere. Syst. Appl. Microbiol. 36:483-489.

Schroeder, B. K., and du Toit, L. J. 2009. First report of Enterobacter cloacae causing onion bulb rot in the Columbia Basin of Washington State. Plant Dis. 93:323.

Schroeder, B. K., Waters, T. D., and du Toit, L. J. 2010. Evaluation of onion cultivars for resistance to Enterobacter cloacae in storage. Plant Dis. 94: 236-243.

Schwartz, H. F., and Mohan, S. K. 2008. Compendium of Onion and Garlic Diseases and Pests, 2nd ed. American Phytopathological Society, St. Paul, MN.

Schwartz, H. F., and Otto, K. 2000. First report of a bulb decay of onion by Enterobacter cloacae in Colorado. Plant Dis. 84:808.

Sotokawa, N., and Takikawa, Y. 2004. Occurrence of bacterial rot of onion bulbs caused by Burkholderia cepacia in Japan. J. Gen. Plant Pathol. 70:348-352.

Vandamme, P., and Peeters, C. 2014. Time to revisit polyphasic taxonomy. Antonie Leeuwenhoek 106:57-65.

Whitby, P. W., Pope, L. C., Carter, K. B., LiPuma, J. J., and Stull, T. L. 2000 Species-specific PCR as a tool for the identification of Burkholderia gladioli. J. Clin. Microbiol. 38:282-285.

Winsor, G. L., Khaira, B., Van Rossum, T., Lo, R., Whiteside, M. D., and Brinkman, F. S. L. 2008. The Burkholderia Genome Database: Facilitating flexible queries and comparative analyses. Bioinformatics 24:2803-2804.

Yohalem, D. S., and Lorbeer, J. W. 1994. Intraspecific metabolic diversity among strains of Burkholderia cepacia isolated from decayed onions, soils, and the clinical environment. Antonie Leeuwenhoek 65:111-131.

Zaid, A. M., Bonasera, J. M., and Beer, S. V. 2011. First report of Enterobacter bulb decay of onions caused by Enterobacter cloacae in New York. Plant Dis. 95:1581.

Zaid, A. M., Bonasera, J. M., and Beer, S. V. 2012. OEM-A new medium for rapid isolation of onion-pathogenic and onion-associated bacteria J. Microbiol. Methods 91:520-526. 